\title{
Energy and Exergy analysis of a Power Plant and Adoption of OPCAN Power Box for Improving Productivity
}

\author{
Mr. A. Suresh ${ }^{1}$ and Dr. Manjeet Kharub ${ }^{2}$ \\ ${ }^{1}$ Asst. Professor, CVR College of Engineering/Mechanical Engg. Department, Hyderabad, India \\ Email: suri0341@gmail.com \\ ${ }^{2}$ Asst. Professor, CVR College of Engineering/Mechanical Engg. Department, Hyderabad, India \\ Email: manjeetkharub@gmail.com
}

\begin{abstract}
Most of the electric energy which the world has utilized is generated from coal or gas based on thermal power plants. These power plants have increased the pollution to the maximum extent. In addition to this the population on the world has multiplied as well as their needs. Therefore, there is a scope for the enhancement of the power plants. All these factors have helped to write this research paper. It is based on the thermal power plant located in Ramagundam of Telangana state, India. Power plant performance evaluation is one of the important processes towards the optimization of its performance. Here in this research power plant performance is evaluated based on first law of thermodynamics (energy analysis) and second law of thermodynamics (exergy analysis) and after that organic rankine cycle based opcan power box is introduced in the power plant. By adopting it the performance of the plant is calculated, after that a comparison is made among the efficiencies with energy analysis, exergy analysis and plant efficiency after, before installation of the opcan power box. For all the components the exergy analysis based efficiency is less than efficiency based on energy analysis. The efficiencies of boiler, turbine using energy analysis are more compare with exergy analysis. In addition to this the efficiency of power plant before installation of opcan power box is calculated as $45 \%$ and after the installation of the opcan power box it is computed as $\mathbf{4 6 . 0 7 \%}$. It indicates that for a $500 \mathrm{MW}$ capacity power plant an extra electricity of $6.7 \mathrm{MW}$ power is produced without altering the input fuel quantity. The net increase of efficiency of $1.07 \%$ indicates that $2-3 \%$ of reduced pollutants.
\end{abstract}

Index Terms: energy analysis, exergy analysis, opcan power box, efficiency

\section{INTRODUCTION}

Electricity is one of the important source of energy to the mankind. Most of the electric energy producing using the conventional sources those are actually making huge lose to the environment. This is the main reason behind the development of the un conventional sources of energy. But the amount of unconventional energy produced is not at all sufficient to the mankind because of many reasons. On the other hand, there is a equal responsibility to reduce the pollutants from the existing conventional coal or gas based thermal power plants. This research paper has focused exactly on this issue to reduce the amount of harmful gases from the power plants for per unit electricity generation. This is achieved by analyzing the power plant performance using energy analysis and then exergy analysis. By doing these analyses the exact picture of power balance has obtained. After archiving the exact picture of power distribution using the energy balance. A new discovery of opcan power box is attached to the existing power plant. The net effect of this installation is critically analyzed for performance evaluation. This in turn shows a significant amount of power outcome. If a plant can produce a megawatt of electricity with the same input and output quantities, it is a welcoming situation to the mankind. Here in this case the plant could produce an extra electricity of about $6.7 \mathrm{MW}$ with a $500 \mathrm{MW}$ power plant.

The analysis is carried out on coal based thermal power plant located in Ramagaundam of Telangana state in India. As a part of the existing research the first step to carry out the work is energy analysis. The energy analysis is a systematic process of analyzing the energy interactions in the system using the thermodynamic principles. Basically, the energy analysis is works on the principle of first law of thermodynamics; it is a law of conservation of energy. During the analysis only boiler and turbine are considered for the analysis because of the priority of these machines. After finding the efficiencies of individual machines the overall efficiency is calculated. After that the exergy analysis is made to the boiler and turbine. Exergy analysis concerns with the available part of the energy. The efficiency of boiler and turbine using exergy analysis are dropped down compared with the energy analysis.

On the other hand, there are many numbers of scholars working over the betterment of the power plants performance or efficiency. Acharya Chirag al [1] in their paper suggested that process parameters must be divided based on the priority basis and out of them those which are making the maximum effect must be separated as decision parameters and they must be analyzed using the perato's principle. And during the analysis the pump work may be neglected as compared with the boiler and turbine. I. S. Jacobs al [2] have found that working over the efficiency calculations will enhance the power plant performance in a better way than many other methods. And they have yielded a solution by optimizing the input energy through the boiler from economizer.

Plant performance relies on the performance of the components in it. Hence there is a significant importance made on the components of the power plants such as boiler and turbine. As a part of that it is emphasized that the available energy is a critical parameter to be analyzed to 
calculate the efficiency. Hence at first the boiler and turbine efficiencies are calculated based on the input and output energy values. Then they are compared for the understanding of difference among the values.

After that the organic rankine cycle based opcan power box is used to lift the power output of the power plant. Basically, opcan power box is a set of construction to use the exhaust heat to produce electricity. This machine utilizes the npentane as the working fluid. And it is best suited for the power plants based on the working principle of thermal energy. Because the working fluid that is used in the opcan power box has the property to get vaporized at low temperatures compared with the water. By making this analysis the power plants efficiency is improved by about $1.07 \%$. This is a significant value because of no extra fuel input and no pollution from the power plant. And the box can operate with less noise and low space compared to the conventional power plant. The detailed methodology and work is briefed below.

\section{EXPERIMENTATION}

The work is an outcome of critical analysis of the power plant components and as well as the effect of mounting the opan power box for the exiting power plant. The detailed methodology is given in figure 1 .

\section{Nomenclature:}

$\mathrm{Q}=$ Heat input in $\mathrm{kJ} / \mathrm{kg}$

$\mathrm{W}=$ Work input in $\mathrm{kJ} / \mathrm{kg}$

$\mathrm{P}=$ Pressure in bar

$\mathrm{T}=$ Temperature in ${ }^{\circ} \mathrm{C}$

$\mathrm{h}=$ enthalpy in $\mathrm{kJ} / \mathrm{kg}$

$\mathrm{s}=$ entropy in $\mathrm{Kj} / \mathrm{kg}$

$\mathrm{x}=$ dryness fraction

$\mathrm{m}_{\mathrm{f}}=$ mass flow rate in $\mathrm{kg} / \mathrm{sec}$

$\mathrm{C}_{\mathrm{v}}=$ Specific heat in $\mathrm{kJ} / \mathrm{kg}$

$\varepsilon=$ specific energy in $\mathrm{kJ} / \mathrm{kg}$

$\varepsilon_{\mathrm{k} . \mathrm{e}}=$ exergy due to velocity (or) kinetic energy in $\mathrm{Kj} / \mathrm{kg}$

$\varepsilon_{\text {p.e }}=$ exergy due to potential energy in $\mathrm{kJ} / \mathrm{kg}$

$\varepsilon_{\mathrm{ph}}=$ physiccal exergy in $\mathrm{kJ} / \mathrm{kg}$

$\mathrm{V}=$ Volume in $\mathrm{m}^{3} / \mathrm{kg}$

$\mathrm{dh}=$ change in enthalpy

$\mathrm{ds}=$ change in entropy

$\mathrm{dP}=$ change in pressure

$\mathrm{dV}=$ change in volume

$\mathrm{dT}=$ change in temperature

$\eta=$ efficiency

$h_{f^{-}}$is the specific enthalpy of the saturated fluid

$\mathrm{h}_{\mathrm{g}}$ - is the specific enthalpy of the saturated gas/vapor

$\mathrm{h}_{\mathrm{fg}}$ - is the difference of the specific enthalpy values of the substances

$\mathrm{E}=$ physical exergy

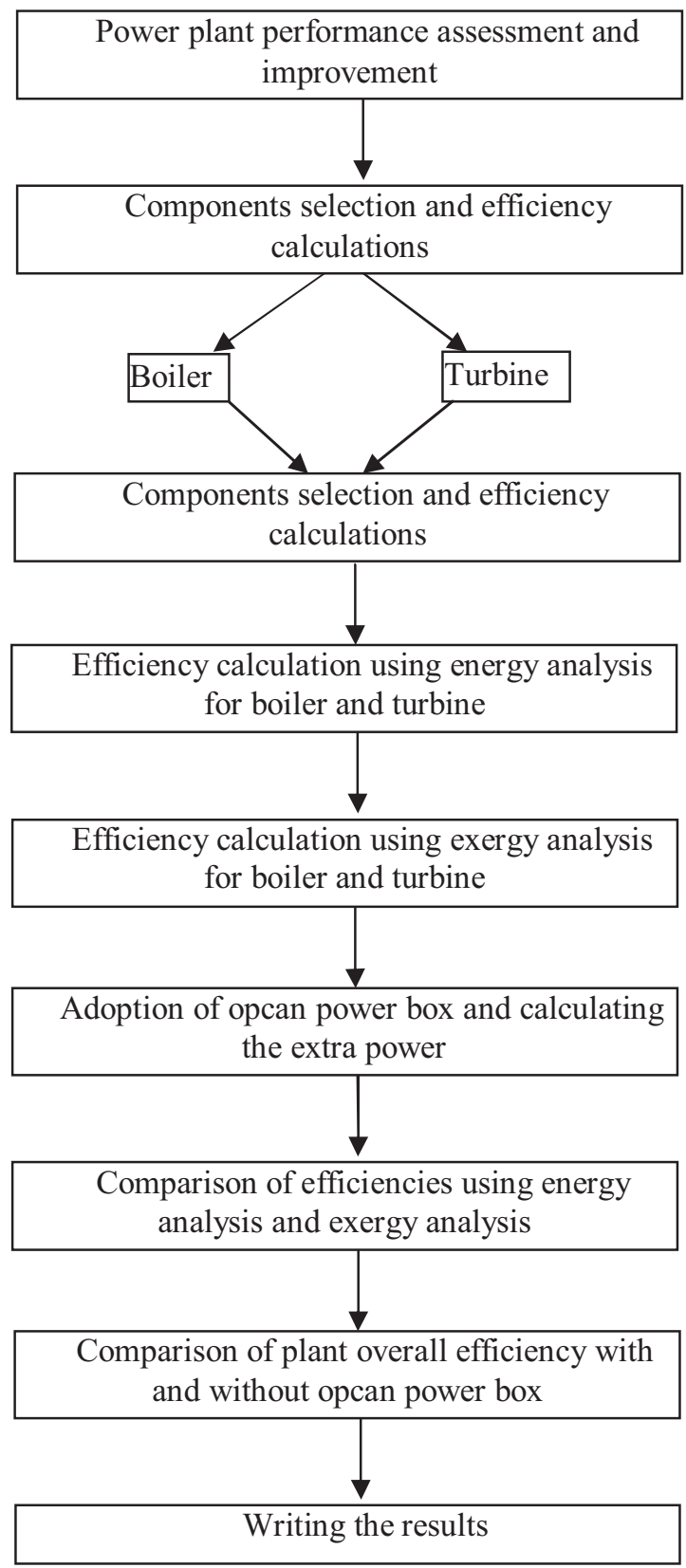

Figure 1: Flow chart describing the methodology of work

III. AnAlysis

The energy and exergy analysis is made by the following assumptions.

- The working parameter values for the power plant usually vary based on the seasonal variations and here the values are considered in winter season.

- The auxiliary power consumption is fixed value and will not vary.

- There are no miscellaneous effects affecting the plant performance.

\section{A. Energy Analysis}

Considering $1 \mathrm{~kg}$ of fluid:

Applying steady flow energy equation to boiler, turbine, condenser and pump. 
1 For boiler (as control volume),

$$
\begin{aligned}
& \mathrm{h}_{\mathrm{f} 4}+\mathrm{Q}_{1}=\mathrm{h}_{1} \\
& \mathrm{Q}_{1}=\mathrm{h}_{1}-\mathrm{h}_{\mathrm{f} 4}
\end{aligned}
$$

2. For turbine (ascontrol volume),

$\mathrm{h}_{1}=\mathrm{W}_{\mathrm{T}}+\mathrm{h}_{2}$ where $\mathrm{W}_{\mathrm{T}}=$ turbine work

$$
\mathrm{W}_{\mathrm{T}}=\mathrm{h}_{1}-\mathrm{h}_{2}
$$

3. For condenser,

$$
\begin{aligned}
& \mathrm{h}_{2}=\mathrm{Q}_{2}+\mathrm{h}_{\mathrm{f} 3} \\
& \mathrm{Q}_{2}=\mathrm{h}_{2}-\mathrm{h}_{\mathrm{f} 3}
\end{aligned}
$$

4. For the feed pump,

$$
\begin{aligned}
& \mathrm{h}_{\mathrm{f} 3}+\mathrm{W}_{\mathrm{p}}=\mathrm{h}_{\mathrm{f} 4} \\
& \mathrm{~W}_{\mathrm{P}}=\mathrm{h}_{\mathrm{f} 4}-\mathrm{h}_{\mathrm{f} 3}
\end{aligned}
$$

5. Rankine cycle efficiency:

$$
\begin{aligned}
& \mathrm{n}_{\text {Rankine }}=\mathrm{W}_{\text {net }} / \mathrm{Q}_{1} \\
& =\left\{\left(\mathrm{h}_{1}-\mathrm{h}_{2}\right)-\left(\mathrm{h}_{\mathrm{f} 4}-\mathrm{h}_{\mathrm{f3}}\right)\right\} /\left(\mathrm{h}_{1}-\mathrm{h}_{\mathrm{f} 4}\right)
\end{aligned}
$$

The feed pump handles liquid water which is incompressible which means with increase in pressure its density or specific volume undergoes a small change .Using general property relation for reversible adiabatic compression, it can be taken as $\mathrm{TdS}=\mathrm{dh}-\mathrm{Vdp}$

Since $\quad \mathrm{dS}=0$

Therefore $\mathrm{dh}=\mathrm{vdp}$

$\Delta \mathrm{h}=\mathrm{v} \Delta \mathrm{p}$

$\mathrm{h}_{\mathrm{f} 4}-\mathrm{h}_{\mathrm{f} 3}=\mathrm{V}_{3}\left(\mathrm{p}_{1}-\mathrm{p}_{2}\right)$

When $\mathrm{p}$ is in bar \& $\mathrm{V}$ is in $\mathrm{m}^{3} / \mathrm{kg}$, then it becomes

\begin{tabular}{|c|c|c|c|c|}
\hline $\begin{array}{c}\mathrm{S} \\
\text { No }\end{array}$ & Pressure & Temperature & Enthalpy & $\begin{array}{l}\text { Dryness } \\
\text { fraction }\end{array}$ \\
\hline 1 & $\begin{array}{c}\mathrm{P}_{1}=160 \\
\text { bar }\end{array}$ & $\mathrm{T}_{1}=450^{\circ} \mathrm{C}$ & $\mathrm{h}_{1}=2600 \mathrm{~kJ} / \mathrm{Kg}$ & \\
\hline 2 & $\begin{array}{c}\mathrm{P}_{1}{ }^{\prime}=160 \\
\text { bar }\end{array}$ & $\mathrm{T}_{1}{ }^{\prime}=540^{\circ} \mathrm{C}$ & $\mathrm{h}_{1}=3420 \mathrm{~kJ} / \mathrm{Kg}$ & \\
\hline 3 & $\begin{array}{c}\mathrm{P}_{2}=50 \\
\text { bar }\end{array}$ & $\mathrm{T}_{2}=350^{\circ} \mathrm{C}$ & $\mathrm{h}_{2}=3060 \mathrm{~kJ} / \mathrm{Kg}$ & \\
\hline 4 & $\begin{array}{c}\mathrm{P}_{2}{ }^{\prime}=50 \\
\text { bar }\end{array}$ & $\mathrm{T}_{2}{ }^{\prime}=540^{\circ} \mathrm{C}$ & $\begin{array}{l}\mathrm{h}_{2}{ }^{\prime}=3540 \\
\mathrm{~kJ} / \mathrm{Kg}\end{array}$ & \\
\hline 5 & $\mathrm{P}_{3}=2 \mathrm{bar}$ & $\mathrm{T}_{3}=130^{\circ} \mathrm{C}$ & $\mathrm{h}_{3}=2710 \mathrm{~kJ} / \mathrm{Kg}$ & \\
\hline 6 & $\mathrm{P}_{4}=1 \mathrm{bar}$ & $\mathrm{T}_{4}=70^{\circ} \mathrm{C}$ & $\begin{array}{l}\mathrm{h}_{4}=2585.505 \\
\mathrm{~kJ} / \mathrm{Kg}\end{array}$ & $\mathrm{x}=0.96$ \\
\hline 7 & $\mathrm{P}_{5}=1 \mathrm{bar}$ & $\mathrm{T}_{5}=70^{\circ} \mathrm{C}$ & $\begin{array}{l}\mathrm{h}_{5}=419.5 \\
\mathrm{~kJ} / \mathrm{Kg}\end{array}$ & \\
\hline
\end{tabular}

$$
\mathrm{h}_{\mathrm{f} 4}-\mathrm{h}_{\mathrm{f} 3}=\mathrm{V}_{3}\left(\mathrm{p}_{1}-\mathrm{p}_{2}\right) \times 10^{5} \mathrm{~J} / \mathrm{kg}
$$

The feed pump term $\left(\mathrm{h}_{\mathrm{f} 4}-\mathrm{h}_{\mathrm{f} 3}\right)$ being a small quantity in comparison with turbine work, $\mathrm{W}_{\mathrm{T}}$, is usually neglected, especially when the boiler pressures are low.

Then $\eta_{\text {Rankine }}=\mathrm{h}_{1}-\mathrm{h}_{2} / \mathrm{h}_{1}-\mathrm{h}_{\mathrm{f} 4}$

Properties of steam are shown in the below table I:

TABLE. I

PROPERTIES OF STEAM IN 500MW NTPC POWER PLANT

\section{Boiler:}

The water from reservoir from reservoir entered in to the economizer from the sump or reservoir. Hence point 1 (here after shown as $\mathrm{h}_{1}, \mathrm{~s}_{1}, \mathrm{P}_{1}$ etc) can be considered as the economizer exit. The fluid then goes to the drum where purification of stream and also separation takes place. After that the steam enters into super heater, the exit of it is considered as point ( $\left.1^{\prime}\right)$, then the steam is supplied to High pressure turbine, from there, as the steam is expanded it is again sent in to boiler for reheating by reheaters. Then the steam is sent in to Low pressure turbine.

Briefly the boiler consists of Economizer coils, super heater coils and reheater coils. The heat quantity given to the boiler will be by burning of coal with the air in the furnace and that will be equal to mass flow rate of the coal multiplied by the calorific value.

The calorific value of the coal that is using there is $\mathrm{C}_{\mathrm{V}}=$ $4000 \mathrm{kCal} / \mathrm{Kg}$

$=956.93 \mathrm{~kJ} / \mathrm{Kg}$

And the mass flow rate of the coal will be $\left(\mathrm{m}_{\mathrm{f}}\right)=320 \mathrm{~T} / \mathrm{hr}$

$=1152 \mathrm{Kg} / \mathrm{sec}$

So the input power given to the boiler $=\left(\mathrm{m}_{\mathrm{f}}\right) * \mathrm{C}_{\mathrm{V}}=(1152$ $\mathrm{Kg} / \mathrm{sec}) \times(956.93 \mathrm{~kJ} / \mathrm{Kg})=1102383.36 \mathrm{~kJ} / \mathrm{sec}=$ $1102.383 \mathrm{~kW}$

And due to this input power the water gets converted in to steam, so totally in the three forms energy transfer will be there, viz,

i) Economizer

Change in enthalpies $\left(\mathrm{h}_{1}-\mathrm{h}_{2}\right)=2220.3 \mathrm{~kJ} / \mathrm{kg}$

ii) Super heater

Change in enthalpies $\left(\mathrm{h}^{\prime}{ }_{1}-\mathrm{h}_{1}\right)=780 \mathrm{~kJ} / \mathrm{kg}$

iii) Re heater

Change in enthalpies $\left(\mathrm{h}_{2}-\mathrm{h}_{1}{ }_{1}\right)=360 \mathrm{~kJ} / \mathrm{kg}$

Then the boiler efficiency is given by $\eta=\left(\left\{\mathrm{dh}^{*} \mathrm{~m}_{\mathrm{f}}\right\}\right.$ of economizer) / (input energy $\left\{\mathrm{mf}^{*} \mathrm{CV}\right\}$ )

$$
\begin{aligned}
& =(2220.3 \times 430.55) /(1102383.36) \\
& =86.7 \%
\end{aligned}
$$

\section{Turbine:}

In the turbine there are two stages will be there,

viz., $\quad$ i) High pressure turbine

ii) Low pressure turbine

The net work done by the High pressure turbine $=\mathrm{m}_{\mathrm{f}} *\left(\mathrm{~h}^{\prime}{ }^{-}{ }^{-}\right.$ $\mathrm{h}_{2}$ )

$$
\begin{aligned}
& =\{1550 * 18 / 5\} *\{360\} \\
& =2008800 \mathrm{~kW}
\end{aligned}
$$

The net work done by the Low Pressure turbine $=\mathrm{m}_{\mathrm{f}}$ $*\left(\mathrm{~h}^{\prime}{ }_{2}-\mathrm{h}_{4}\right)$

$$
\begin{aligned}
& =\{1550 * 18 / 5\} *\{954.916\} \\
& =5328431.28 \mathrm{~kW}
\end{aligned}
$$

And the input energy is $=\left\{\left(\mathrm{h}_{5}-\mathrm{h}_{1}\right) * \mathrm{~m}_{\mathrm{f}}\right\}$ of combustion products $+\left\{\left\{\left(\mathrm{h}_{1}{ }^{\prime}-\mathrm{h}_{1}\right) * \mathrm{~m}_{\mathrm{f}}\right\}\right.$ energy of super heated steam $\}+$

$\left\{\left\{\left(\mathrm{h}_{2}-\mathrm{h}_{2}{ }^{\prime}\right) * \mathrm{~m}_{\mathrm{f}}\right\}\right.$ energy of re heated steam $\}$ $=[\{320 * 18 / 5\} *\{4000 / 4.18\}]+[\{1550 \times 18 / 5\} *\{780\}]+$ $[\{1550 * 5 / 18\} *\{480\}]$

$=1102392.345+4352400+2287800 \mathrm{~kW}$

$=7742592.345 \mathrm{~kW}$

Therefore, $\eta_{\text {Turbine, I law }}=$ (net work generated by HPTurbine) / (heat supplied to the steam to run the HPTurbine)

$$
\begin{aligned}
& =((2008800+532841.28) / 7742592.345) \\
& =(7337231.28 / 7742592.345) \\
& =0.94=94 \%
\end{aligned}
$$

\section{Condenser:}

From the data the mass flow rate of the steam at the inlet of the turbine $=334.35 \mathrm{Kg} / \mathrm{sec}$ with the temperature of $70 \mathrm{deg}$ C. 


$$
\text { The input quantity }=\mathrm{m}_{\mathrm{f}} * \mathrm{~h}_{\mathrm{fg}}=334.8 * 2431=813898.8
$$
$\mathrm{kW}$

In the condenser the rate of heat transfer will be equal to: $\left(\mathrm{m}_{\mathrm{f}}\right) * \mathrm{C}_{\mathrm{p}} * \mathrm{dT}$

$$
=4868.106 * 4.2 * 40=817841.8 \mathrm{~kW}
$$

Therefore the effectiveness of the condenser $=$ (input quantity / output quantity) $=0.995$

\section{Pump:}

The pump work has been neglected. And more over there is auxiliary power consumption (A.P.C), which includes the power required to run the plant in all the sectors.

And that will be equal to: $6 \%$

Note: A.P.C. includes power given to all fans, households of the plant, pump etc.

\section{A. Energy balance}

Energy balance includes the balancing of input and output energies.

The input energy for the total plant is $=\left(\mathrm{m}_{\mathrm{f}}\right) * \mathrm{C}_{\mathrm{V}}=(1152$ $\mathrm{Kg} / \mathrm{sec}) *(956.93 \mathrm{~kJ} / \mathrm{Kg})$

$$
=1102383.36 \mathrm{~kJ} / \mathrm{sec}=1102.383 \mathrm{MW}
$$

And the output will be: $500 \mathrm{MW}$ constant.

Then the overall efficiency of the plant will be equal to: $(500 / 1102.383) \quad=45 \%$

Thermal efficiency: $\left\{\left(\left(\mathrm{h}^{\prime}{ }_{1}-\mathrm{h}_{2}\right)-\left(\mathrm{h}^{\prime}{ }_{2}-\mathrm{h}_{4}\right)\right) /\left(\left(\mathrm{h}_{1}-\mathrm{h}_{5}\right)-\left(\mathrm{h}_{2}-\mathrm{h}_{2}\right)\right)\right\}$

$$
=37 \%
$$

And the Auxiliary Power Consumption

$30 \mathrm{MW}=(30 / 500) \quad=6 \%$

And the heat transfer losses due to bad insulation= (approximately) $\quad=2 \%$

The power loss in condenser is equal to: $440.15 \mathrm{MW}=$ (approximately) $\quad=40 \%$

And finally the power loss by flue gases will be equal to $=$ $15 \%$ (remaining) .

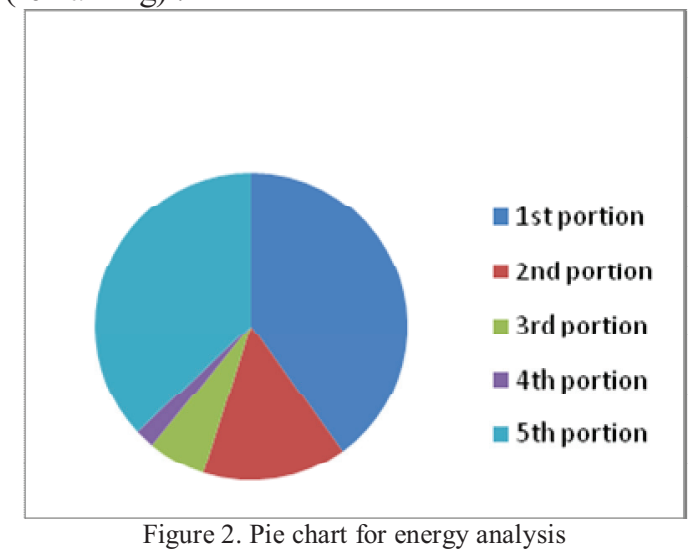

$\begin{array}{lll}\text { Portion 1 } & \text { Condenser losses } & =40 \% \\ \text { Portion 2 } & \text { Flue gases losses } & =15 \% \\ \text { Portion 3 : } & \text { A.P.C. } & =6 \% \\ \text { Portion 4 : } & \text { Heat Transfer losses } & =2 \% \\ \text { Portion 5 : } & \text { Net power } & =37 \%\end{array}$

\section{B. Exergy analysis}

The exergy analysis is the combination of the First and Second laws of thermodynamics. In this analysis the heat does not have the same value as the work, and the exergy losses represent the real losses of work. When analyzing novel and complex thermal systems, experience needs to be supplemented by more rigorous quantitative analytical tools $[1,2]$. Exergy analysis provides those tools and it helps in locating weak spots in a process. This analysis provides a quantitative measure of the quality of the energy in terms of its ability to perform work and leads to a more rational use of energy. In general, the specific exergy denoted by " $\varepsilon$ " is calculated using the equation as given below.

$$
\varepsilon=\varepsilon_{\mathrm{k} . \mathrm{e}}+\varepsilon_{\mathrm{p.e}}+\varepsilon_{\mathrm{ph}}+\varepsilon_{\mathrm{ch}}
$$

Where, $\varepsilon_{\text {k.e }}$ and $\varepsilon_{\text {p.e }}$ are exergy due to velocity (or) kinetic energy and exergy due to potential energy respectively. $\varepsilon_{\mathrm{ph}}$ is physiccal exergy i.e. exergy due to temperature difference and pressure difference with respect to the reference point and $\varepsilon_{\mathrm{ch}}$ is chemical exergy (i.e due to reactions). In the present analysis, it is assumed that the exergy due to kinetic energy and potential energy are negligible. Also, for the exergy calculations, the atmospheric temperature and pressure are taken respectively as $30^{\circ} \mathrm{C}$ and $101.325 \mathrm{kPa}$.

Exergetic performance analysis is based on second law of thermodynamics. The results obtained from such an analysis can be used as a guide for diminishing the irreversibilities in the power plants and thereby enhancing their performances $[3,4]$. In fact, exergy is a thermodynamic indicator that shows the transformation potential and convertible limit of an energy carrier to maximum theoretical work under the conditions imposed by an environment at given pressure and temperature. In this exergetic performance analysis exergy efficiency and exergy destruction rate of both plant and plant component are determined. In addition, exergy losses per unit power output in the plants are defined and used as a new exergetic performance criterion.

For control volume of any plant component at steady-state conditions, a general equation of exergy destruction rate derived from the exergy balance can be given as equation number $1[8]$.

$$
\begin{aligned}
\dot{E} x_{\mathrm{D}}= & \sum(\dot{E} x)_{\text {in }}-\sum(\dot{E} x)_{\text {out }} \\
& +\left[\sum\left(\dot{Q}\left(1-\frac{T_{\mathrm{o}}}{T}\right)\right)_{\text {in }}-\sum\left(\dot{Q}\left(1-\frac{T_{\mathrm{o}}}{T}\right)\right)_{\text {out }}\right] \pm \dot{W}
\end{aligned}
$$

Where the first two terms of right hand side represent exergy of streams at entry and exit the control volume. The third and fourth terms are the exergy related to heat transfer by heat. Q represents heat transfer rate across the boundary of the system at a constant temperature of T. The last term is work transfer rate to or from the control volume. In this study, only physical exergy by mass flows crossing the control volume is considered and given as equation number $2[9]$.

$$
\dot{E} x=\dot{m}\left[\left(h-h_{0}\right)-T_{0}\left(s-s_{0}\right)\right]
$$

Where, $h$ and $s$ represent specific enthalpy and entropy, respectively $[5,6]$. In the exergetic performance analysis, exergy efficiency gives a measure of the performance of a system or a component. Exergy efficiency of the components in the investigated power plants is defined based on product and fuel approach [7]. 
The exergy analysis or second law efficiency results are computed as follows. In addition to it the opcan power box calculations are also shown below.

\section{Boiler:}

The exergy efficiency of the boiler is calculated as follows input power $=(486.11 *\{(13000-7000))-(298) *(160-150))$ $=1468.05 \mathrm{MW}$

output power $=(430.55 *\{(2905)-298 *(5.3521-1.3027)\})=$ $730.183 \mathrm{MW}$

Hence the efficiency is $=$ output $/$ input $=49.7 \%$

\section{Turbine:}

There are two parts in the turbine. Hence exergy analysis is to be done individually.

For HPT: efficiency:

$$
\begin{aligned}
& \text { Input }=((3420-104.9)-(298) *(6.4481-.3664))= \\
& 1502.75 \mathrm{~kJ} / \mathrm{kg} \\
& \text { Output }=((3060-104.9)-(298 * 96.45-.3664))=
\end{aligned}
$$$$
1142.1 \mathrm{~kJ} / \mathrm{kg}
$$

For LPT: efficiency:

$$
\text { Input }=((3540-104.9)-(298 *(7.09-.366)))=
$$

$1429.56 \mathrm{~kJ} / \mathrm{kg}$

Output $=((2585.084-104.9)-(298 *(7.358-.366))=$

$398.952 \mathrm{~kJ} / \mathrm{kg}$

Efficiency $=27.9 \%$

Therefore the total turbine second law efficiency is equal to:

Total input: $1502.75+1429.56=2932.31 \mathrm{~kJ} / \mathrm{kg}$

Total output: $1142.1+398.952=1541.052 \mathrm{~kJ} / \mathrm{kg}$

Total efficiency: $(1541.052 / 2932.31)=52.5 \%$

\section{Condenser:}

In the condenser the heat Balance equation is:

$\mathrm{Ex}_{1}=\mathrm{m}\left[\left(\mathrm{h}-\mathrm{h}_{\mathrm{o}}\right)-\mathrm{T}_{\mathrm{o}}\left(\mathrm{s}-\mathrm{s}_{\mathrm{o}}\right)\right]$, here $\mathrm{h}=\mathrm{h}_{\mathrm{f}}+\mathrm{x} * \mathrm{~h}_{\mathrm{fg}}$

Therefore, at $\mathrm{T}=70^{\circ} \mathrm{C} \& \mathrm{P}=1 \mathrm{bar}$

From steam tables $\mathrm{h}_{\mathrm{f}}=293.0 \mathrm{~kJ} / \mathrm{kg}, \mathrm{h}_{\mathrm{fg}}=2333.8 \mathrm{~kJ} / \mathrm{kg}$, $\mathrm{s}_{\mathrm{f}}=0.955 \mathrm{k} \mathrm{J} / \mathrm{kgK}, \mathrm{s}_{\mathrm{fg}}=6.800 \mathrm{~kJ} / \mathrm{kgK}$

$$
\begin{aligned}
\mathrm{Ex}_{1}=\mathrm{m}\left[\left(\mathrm{h}-\mathrm{h}_{\mathrm{o}}\right)-\mathrm{T}_{\mathrm{o}}\left(\mathrm{s}-\mathrm{s}_{\mathrm{o}}\right)\right] & \\
& =334.84[(2533.448-417.5)+70(7.483-
\end{aligned}
$$

$1.3037)]=853.362 \mathrm{~kJ} / \mathrm{kgK}$

$$
\mathrm{Ex}_{2}=334.84[(2333.8-293)-70(6.800-0.955)]
$$

$=820.341 \mathrm{~kJ} / \mathrm{kgK}$

$$
\mathrm{Ex}_{3}=334.84[(2459-417.5)-30(8.13236-1.3027)]
$$

$=752.348 \mathrm{~kJ} / \mathrm{kgK}$

The temperature at $\mathrm{Ex}_{4}$ is not known hence it must be found out by the following procedure. From the plant the value of $\mathrm{m}=6450.9 \mathrm{~kg} / \mathrm{sec}$

Then the equation is $=\mathrm{mC}_{\mathrm{p}}\left(\mathrm{T}_{4}-\mathrm{T}_{3}\right)=$ mass flow rate $* \mathrm{~h}_{\mathrm{fg}}$

$$
\text { Then } \mathrm{T}_{4}=60.13^{\circ} \mathrm{C}
$$$$
\mathrm{Ex}_{4}=334.84[(2353.6-417.5)-60.13(7.022-1.3027)
$$

$$
=763.435 \mathrm{~kJ} / \mathrm{kgK}
$$

Exergy $=\mathrm{Ex}_{4}-\mathrm{Ex}_{3} / \mathrm{Ex}_{2}-\mathrm{Ex}_{1}$

$$
\begin{gathered}
=0.3357 \\
\eta=33.57 \%
\end{gathered}
$$

The concept to use this opcan power box in the power plant is to produce more power with the same input. This box will be kept at exit of the Low pressure turbine, so that it can utilize that waste heat from steam and water mixture.
Salient features of the OPCAN power box:

One box can produce $750 \mathrm{~kW}$ of power.

The maximum efficiency of opcan box is $60 \%$.

With the $1200 \mathrm{~kW}$ input power it can produce $750 \mathrm{~kW}$ power.

The input power (ex: compressor) needed to one box $=$ $45 \mathrm{~kW}$

The mass flow rate of the steam at the exit of the Low pressure turbine will be $=334.8 \mathrm{Kg} / \mathrm{sec}$.

Hence $\mathrm{Q}=\mathrm{m}_{\mathrm{f}} * \mathrm{~h}_{\mathrm{fg}}=334.82 * 2431 \mathrm{~kW}$

And that quantity $\mathrm{Q}=\mathrm{m} * \mathrm{cp} * \mathrm{dt}$

$$
\begin{aligned}
& =>813996=\mathrm{m} \times 0.8 \times 40 \\
& =>\mathrm{m}=29071.28 \mathrm{~kg} / \mathrm{sec}
\end{aligned}
$$

\section{OpCAN POWER Box InSTALlation}

The power boxes can be kept individually by supplying the steam to them. In order to install the opcan power boxes the steam required for each box must be calculated. After that based on the available steam number of boxes to be installed will be known.

Therefore steam required for one box is $=\mathrm{m} * \mathrm{Cp} * \mathrm{dT}=$ Q(heat supplied)

$=>\mathrm{m} * 0.8 * 40=1200$

$=>\mathrm{m}=37.5 \mathrm{~kg} / \mathrm{sec}$.

Then the no of power boxes that can be adopted $=334.8$ / $37.5=9$

Hence the total extra power produced is $=9 * 750=$ $6750 \mathrm{~kW}=6.7 \mathrm{MW}$.

\section{RESULTS}

First law of thermodynamic efficiency is calculated to the main components of power plant viz., boiler, turbine, condenser. After calculating the first law efficiency, second law of thermodynamic efficiency known as exergytic efficiency has been calculated. Based on the outcomes of efficiencies it is found that second law efficiency is less than that of first law efficiency. The detailed outcomes of the efficiencies of first law and second law are compared in the below figures. Figure 3 shows the boiler and turbine efficiencies as per the energy and exergy analysis.

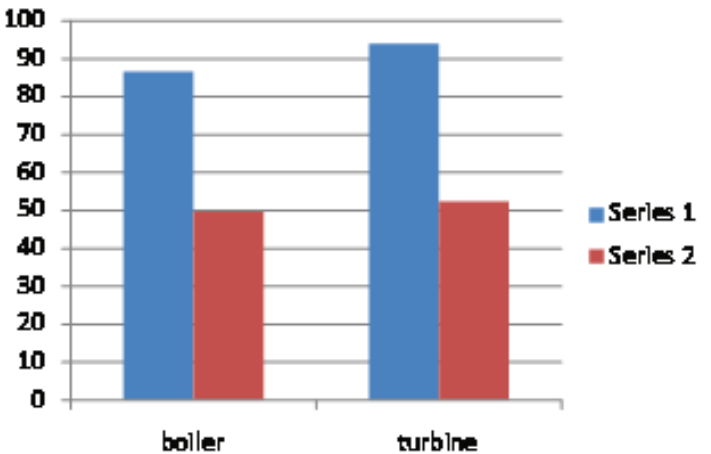

Figure 3. Comparison of I and II law efficiencies applied to boiler and turbine

The boiler efficiency as per energy analysis is $86.7 \%$ shown in blue color in figure 3 and as per exergy analysis it is $49.7 \%$ shown in blue color in figure 3. Similarly, for turbine the efficiencies as per energy and exergy analyses are $94 \%$ (blue color) and $52.5 \%$ (red color) shown in figure 3 respectively. Series 1 in blue color indicates the efficiency as per energy analysis and series 2 in red color indicates the efficiency as per exergy analysis. 
As discussed above, to the existing power plant setup the opcan power boxes are added to produce the extra power from the waste heat, which use escape out to the atmosphere through the chimneys. By installing the opcan power boxes it has been calculated that $6.7 \mathrm{MW}$ of extra power can be produced.

The opcan power boxes are easy to install and maintain hence these can be adopted with ease and less effort. During the process of energy conversion from the waste heat into useful form of electric energy no flue gases will be emitted. This process is economic as well as useful for the mankind to overcome the electricity needs. The efficiency calculations are given below.

Before installing the opcan power boxes

$$
\eta_{\text {overall }}=500 / 1100.4=45 \%
$$

After installing the opcan power boxes

$$
\eta_{\text {overall }}=506.7 / 1100.4=46.07 \%
$$

Increase in efficiency $=1.07 \%$

$\%$ of increase in efficiency $=2.37$

The comparison of efficiencies of the power plant with and without using of opcan power boxes is given below in the figure 4.

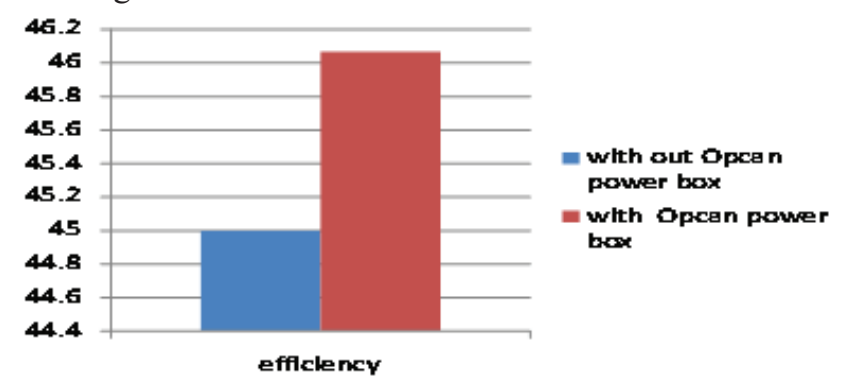

Figure 4. Comparison of efficiency with and without installing opcan power box.

The blue color bar indicates the efficiency of the power plant without using the opcan power box and the red color bar shows the efficiency of the power plant after installing the opcan power box. It can be observed from the above figure that there is an increase of efficiency of 1.07. This is a significant value for a thermal power plant, hence it is advisable to adopt the opcan power boxes to the existing thermal power plants for increasing the efficiency.

\section{Conclusions}

From the above research it can be concluded that the efficiency calculated based on energy analysis for boiler and turbine are more compared to the same done by the exergy analysis. And by installing the opcan power boxes there is significant amount of improvement in the output quantity of power production. $6.7 \mathrm{MW}$ extra power production per 500MW power plant will make an arena for the existing power plants to modify and install the opcan power box for the efficient power production and also as already it is emphasized that as there is no extra input quantity of coal or gas are used in this hence the pollution also reduces. At the end there is a lot of scope for this technology in future to overcome the power demand and reduce the pollution problems.

\section{REFERENCES}

[1] Acharya Chirag1, Prof. Nirvesh Mehta2, Prof. Jaspal Dabhi3, Research paper on Analysis of Boiler losses to improve Unit heat rate of coal fired thermal power plant. International Journal of Advance Engineering and Research Development (IJAERD) Volume 1, Issue 5, May 2014, e-ISSN: 2348 - 4470 , print-ISSN:2348-6406

[2] I. S. Jacobs and C. P. Bean, "Fine particles, thin films and exchange anisotropy," in Magnetism, vol. III, G. T. Rado and H. Suhl, Eds. New York: Academic, 1963, pp. 271-350.

[3] G. Eason, B. Noble, and I. N. Sneddon, "On certain integrals of Lipschitz-Hankel type involving products of Bessel functions," Phil. Trans. Roy. Soc. London, vol. A247, pp. 529-551, April 1955.

[4] J. Clerk Maxwell, A Treatise on Electricity and Magnetism, $3^{\text {rd }}$ ed., vol. 2. Oxford: Clarendon, 1892, pp.68-73.

[5] Vikas Bavane, Pooja Rindhe, Energy Analysis of Thermal Power Plant, International Journal of Research in Advent Technology (IJRAT) (E-ISSN: 2321-9637) Special Issue National Conference "CONVERGENCE 2017", 09th April 2017

[6] Y. Yorozu, M. Hirano, K. Oka, and Y. Tagawa, "Electron spectroscopy studies on magneto-optical media and plastic substrate interface," IEEE Transl. J. Magn. Japan, vol. 2, pp. 740-741, August 1987 [Digests $9^{\text {th }}$ Annual Conf. Magnetics Japan, p. 301, 1982].

[7] M. Young, The Technical Writer's Handbook. Mill Valley, CA: University Science, 1989.

[8] Joong Yong Yi, Kyung Min Kim, Jongjun Lee and Mun Sei Oh, Exergy Analysis for Utilizing Latent Energy of Thermal Energy Storage System in District Heating, Energies 2019, 12, 1391; doi:10.3390/en12071391

[9] MSK. Tony Suryo U, Eflita Yohana, Syarif Dwi Priyanto, Ignatius Apryando M. and Tauviqirrahman, Energy and Exergy Analysis of Steam Power Plant 3rd Unit PT PLN (PERSERO) Centre Unit Generation Tanjung Jati B Use BFPT Modification Cycle, E3S Web of Conferences 125, (2019) https://doi.org/10.1051/e3sconf/2019125 ICENIS 201913003 13003 